\title{
Cord Blood Stem Cell Cryopreservation
}

\author{
Erik J. Woods ${ }^{a, b^{*}}$ \\ Shelly Heimfeld ${ }^{d}$ \\ Karen E. Pollok \\ a The Indiana Cord Blood Bank, \\ ${ }^{b}$ Indiana University School of Medicine, Indianapolis, IN, \\ c University of Washington, \\ dFred Hutchinson Cancer Research Center, Seattle, WA, USA
}

Michael A. Byers ${ }^{a}$

Brandon C. Perry ${ }^{a}$

Jester Purtteman ${ }^{c}$

\section{Key Words}

Umbilical cord blood - Hematopoietic stem cells . Mesenchymal stem cells · Cryopreservation

\section{Summary}

Umbilical cord blood contains hematopoietic stem/progenitor cells that have proven useful clinically to reconstitute the hematopoietic system in children and some adults. Recent studies have suggested that cord blood contains mesenchymal stem/progenitor cells as well, which may have many additional uses on their own or in conjunction with their hematopoietic counterparts. In order to effectively utilize cord blood clinically, it must be frozen and banked. The protocols used for this have largely been adapted from those originally designed for bone marrow hematopoietic stem/progenitor cells, and there is no consensus on optimal procedures for cord blood cells. In this review, the considerations required to develop an ideal cryopreservation strategy are discussed, and an analysis of current literature related to these steps is presented. The closest consensus considering cord blood hematopoietic cells is presented as $5-10 \%$ concentrations of dimethyl sulfoxide (DMSO) using slow cooling and rapid thaw. New data involving a long-term culture-initiating cell (LTC-IC) assay testing such a protocol is also presented in which no statistical difference was observed for 5 vs. $10 \%$ DMSO at cooling rates of $1{ }^{\circ} \mathrm{C} / \mathrm{min}$. The ultimate impact of umbilical cord blood may be far more significant than is currently realized, and overall, clinical data justifies further development of umbilical cord blood banks worldwide. Cryopreservation processing that yields consistent high recovery of functionally viable cells is crucial for the further successful use of this important cell resource.

\begin{tabular}{ll}
\hline KARGER & ( 2007 S. Karger GmbH, Freiburg \\
Fax +497614520714 & Accessible online at: \\
$\begin{array}{l}\text { E-mail Information@Karger.de } \\
\text { www.karger.com }\end{array}$ & www.karger.com/tmh \\
&
\end{tabular}




\section{Introduction}

The term 'stem cell' generally refers to a cell possessing the ability to self-replicate and give rise to daughter cells which undergo an irreversible, terminal differentiation process $[1,2]$. Stem cells from post-natal human origin have been studied extensively from sources such as the epidermis, gastrointestinal epithelium, skeletal muscle, adipose tissue, teeth, bone marrow and umbilical cord blood (UCB). To date, the hematopoietic stem cells originating in the bone marrow have arguably been the most extensively studied [3]. This is due in part to the long history of hematopoietic stem/progenitor cell (HPC) transplantation to treat a broad spectrum of malignant and non-malignant human diseases. Currently, tens of thousands of HPC transplants are performed every year throughout the world [4].

The majority of HPC transplants have been performed using cells derived from bone marrow obtained through allogeneic (both related and unrelated to the recipient) as well as autologous and syngeneic donors. Since human leukocyte antigen(HLA)-compatible related donors are identified for only $25-30 \%$ of patients who could potentially benefit from a transplant procedure, much work has been done to identify unrelated donors. While the identification of unrelated bone marrow donors and transplantation of these units has become more widespread [5], many patients (particularly those of ethnic minorities) in need of a hematopoietic graft do not have identifiable donors. Conservatively, there are at least 5,000 bone marrow transplants that cannot be performed in the USA each year because there is no matched donor available [6]. As a result, investigators have begun more frequently utilizing HLA-matched and -mismatched UCB units from related and unrelated donors as a source of HPCs for bone marrow reconstitution [7-9].

Quantitatively, UCB contains high concentrations of HPCs, averaging around 26,000/ml [6]. This is a much higher concentration than that found in normal adult peripheral blood, and this concentration approaches the levels of HPCs mobilized into the peripheral blood following cytokine and/or chemotherapy administration [6]. The proliferative capacity is higher in HPCs isolated from UCB compared to those obtained from adult bone marrow, with greater replating potential and larger in vitro colonies [6]. Furthermore, nearly one quarter of the total number of UCB-derived HPCs are multipotent while in adult marrow the percentage of multipotent HPCs is only $2-3 \%$ [6]. In addition, there is a greater concentration of longterm culture-initiating cells in UCB than in adult marrow [6]. The results of clinical transplantation of UCB HPC have indicated engraftment in approximately $80-90 \%$ of recipients [7-9]. Additionally, UCB HPC offers several advantages over bone marrow and peripheral blood as a donor product since it is available without risk to mother or infant, is easy to collect, and may produce less graft-versus-host disease (GVHD) in the recipient $[10,11]$.
While UCB has been known as a rich source of HPCs capable of providing hematopoietic reconstitution in human patients since the late 1980s [12], more recently it has also been investigated as a potential source of mesenchymal stem/progenitor cells (MPCs). These MPCs have been isolated from UCB, and under specific culture conditions they develop into homogeneous plastic-adherent cell populations that exhibit fibroblastlike morphology and typical mesenchymal-like immunophenotypes [13]. Unlike their hematopoietic counterparts, UCBderived MPCs are readily propagated and expanded in culture. Under correct cytokine stimulation, these cells also exhibit the mesenchymal lineage capacity to form bone, fat and cartilage, and express mRNAs of multi-lineage genes including SDF-1, NeuroD and VEGF-R1 [13]. These MPCs may potentially have immunomodulatory properties as well as other characteristics that have been demonstrated in vivo for bone marrow-derived MPCs, including facilitation of recovery after HPC transplantation [14], prevention and treatment of GVHD [15], treatment of bone disorders such as osteogenesis imperfecta [16] and metabolic disorders [17].

Interestingly, while MPCs have been derived from cryopreserved UCB units, these units were prepared and cryopreserved using methods prescribed for HPC preservation, and optimized methods specific to this cell type have yet to be fully investigated $[13,18]$.

\section{Development of Optimized Procedures for Cord Blood Stem Cell Cryopreservation}

While discussing freezing and banking of UCB, it is important first to put into context what is actually being frozen. The HPCs and MPCs are within the mononuclear cell (MNC) subset, and because of this red blood cells as well as excess plasma are typically removed from these samples prior to banking to reduce bulk. While the HPCs can be further isolated from the MNC subset through CD34+ cell selection, this is typically not done, both for convenience and to conserve as many HPCs as possible. Because UCB HPCs were thought to be very similar to their bone marrow-derived counterparts, initial protocols were derived from those used for the preservation of bone marrow and peripheral blood [19]. However, there is not substantial evidence that such protocols are optimal for UCB sources [20].

To develop a successful cell cryopreservation strategy, the key events inherent to freezing a biological cell must be considered, and each potential source of damage should be mitigated if at all possible. A simple way to organize these steps includes: i) determining the cryoprotectant (CPA) type and concentration, ii) determining the cooling and warming rates, and iii) preparation of cells for use (including any washing procedures). In recent years there have been several investigations into optimizing these steps for UCB stem/progenitor cells (for a recent review of the fundamental aspects of cryobiology, 
specifically in regards to applications in transfusion medicine, please see $[21,22])$.

\section{Choosing a CPA and Concentration}

Currently, most UCB cryopreservation protocols begin with equilibration of the cells in molar concentrations of the plasma membrane-permeating molecule dimethyl sulfoxide (DMSO) [19]. Some groups elect to add a large molecular weight, non-permeable CPA as well, such as dextran or hydroxyethyl starch (HES). The permeable CPAs such as DMSO protect not by specific chemical action but by their colligative properties [20] to i) reduce the fraction of the cellular constituents and extracellular solution frozen at any given temperature, ii) suppress the salt concentration in solution, and (iii) reduce harmful cell shrinkage at any given temperature. Several mechanisms of action have been proposed for non-permeable CPAs. In the presence of macromolecular compounds, a proportion of water does not crystallize during the freezing process, thus reducing the solute concentration and potentially reducing the potential for solution effects injury [23, 24]. These also potentially protect by dehydrating the cells through osmotic pressure (reducing the likelihood of intracellular ice formation) and by stabilizing the cell membranes. The addition of permeable CPAs such as DMSO causes cells to shrink transiently as water initially exits, then reswell as the DMSO (along with water) penetrates, resulting in equilibration $[25,26]$. The magnitude of the cellular volume excursion depends not only on the manner of the addition and removal of the DMSO but also on the inherent permeability of the cells to DMSO and water [27] and the temperature at which exposure occurs [28, 29]. Upon addition of a non-permeating CPA, cells shrink as water exits to relieve the osmotic dis-equilibrium, and remain shrunken until the solute is removed or diluted. In this instance, the magnitude of the volume excursion will be dependent on the concentration of nonpermeating CPA and the permeability of the cell to water only.

Although glycerol was originally used as the permeable CPA for bone marrow HPCs [30], DMSO is now the permeable CPA of choice, regardless of the addition of a non-permeant CPA, for bone marrow-, peripheral blood-derived HPCs and UCB HPCs. This is arguably a good choice because DMSO is available in clinical grade preparations and is known to be much more permeable to most cells than glycerol, often being a 'default' cryoprotectant for laboratory use as well. While virtually all clinical banks use DMSO in their cryopreservation processing, the most appropriate concentration for UCB HPCs has still been a point of some controversy. Concentrations ranging from 5 to $20 \%(0.64-2.56 \mathrm{~mol} / \mathrm{l})$ have been investigated with some differing results observed depending on how recovery/viability was determined. Sputtek et al. [31] reported optimal cryopreservation of peripheral blood HPCs using at least 5\% DMSO. Donaldson et al. [32] observed good recovery of $\mathrm{CD} 34+$ cells from UCB cryopreserved with $5 \%$
DMSO as well. However, many groups, including most in the USA, use a protocol based on that of Rubenstein et al. [19] which relies on $10 \%$ DMSO. Hunt et al. [33, 34] observed optimal results using 10\% DMSO as evaluated by membrane integrity and CFU (colony forming unit) analysis. Meyer et al. [35] also indicated optimal results with $10 \%$ DMSO as measured by CD34+ cell recovery and CFU analysis. More recently, Skoric et al. [20] presented data indicating 5\% DMSO was optimal also based on CD34+ cell recovery and CFU analysis. Our group previously analyzed the fundamental cryobiological characteristics of isolated CD34+ cells from UCB and used a mathematical model to determine theoretically optimized procedures for cryopreserving these cells $[28,29]$. The theoretically optimized process, which called for 5\% DMSO, was compared to a $10 \%$ DMSO control and evaluated by $\mathrm{CFU}$ analysis and transplant into an irradiated NOD/SCID mouse model to determine engraftment. These studies indicated, while not statistically significant, slightly better results were obtained with 5\% DMSO [29]. Importantly, however, unlike the other studies referenced, this evaluation was performed on CD34+ cells isolated from mononuclear cell (MNC) preparations, not on the whole $\mathrm{MNC}$ components as is commonly done for practical reasons clinically.

The addition procedure for DMSO has also been evaluated as a potential source for protocol improvement. Two issues are important in this regard, the osmotic tolerance of the cells and the biological sensitivity to DMSO from a chemical perspective (e.g. toxicity). Historically, DMSO has been thought to exert chemical toxic effects on cells resulting in loss of proliferative potential of HPCs [36]. For these reasons, early protocols for its use in HPC cryopreservation have called for its introduction at lower than ambient (e.g. $4{ }^{\circ} \mathrm{C}$ ) temperature to reduce the toxic effects, presumably by slowing down biological metabolism. The commonly followed methods of Rubenstein et al. [19] still follow this practice. However, recent re-examination of this topic through independent studies has shown that exposure to concentrations of $8-10 \%$ DMSO at ambient temperature for up to $1 \mathrm{~h}$ has no effect on bone marrow-derived HPCs as assayed by in vitro colony formation [37, 38]. In studies of the fundamental cryobiology of these cells, Hunt et al. [34] also indicated that at a $10 \%$ concentration temperature is unlikely to be of practical importance with regard to toxicity. This is important because the temperature dependence of permeability has been well documented, and it is generally accepted that cells are more sensitive to osmotic damage at lower temperatures [39]. Our group previously reported DMSO can be added to CD34+ cells isolated from UCB to reach final concentrations of $10 \%$ in a single step at $22{ }^{\circ} \mathrm{C}$ without causing significant osmotic damage, and cells processed in this manner engrafted well in the NOD/SCID mouse model [29]. This strategy has recently been confirmed in other studies in which a rapid addition of $10 \%$ DMSO resulted in optimal CD34+ cell recovery and CFU results in freezing UCB MNCs [35]. 


\section{Choosing a Cooling Rate}

For the most part, slow cooling protocols (e.g. $1-5{ }^{\circ} \mathrm{C} / \mathrm{min}$ ) seem to be the consensus among most laboratories for cryopreservation of UCB HPCs. This likely allows the cells to gradually dehydrate in response to a growing ice phase and increasing extracellular solute concentration [40]. Hunt et al. [34] demonstrated that even with increased concentrations of DMSO, faster cooling rates $\left(10^{\circ} \mathrm{C} / \mathrm{min}\right.$ and $\left.100{ }^{\circ} \mathrm{C} / \mathrm{min}\right) \mathrm{re}-$ sulted in significant drop-off in viability, and Donaldson et al. [32] even reported a statistically significant difference in viability between cooling at 1 and $5^{\circ} \mathrm{C} / \mathrm{min}$. However, a difference of opinion remains regarding the use of controlled cooling to achieve these rates versus a more simplified uncontrolled method whereby prepared cells are placed into a mechanical freezer for cooling (e.g. 'dump-freezing' method). Many groups have relied on various versions of the 'dumpfreezing' method for cryopreservation of peripheral blood HPCs with good results and post-transplant engraftment [41, 42]. Depending on how the cell sample is packaged, 'dump freezing' using a standard $-85^{\circ} \mathrm{C}$ freezer can result in cooling rates of $1-4{ }^{\circ} \mathrm{C} / \mathrm{min}$, which is in the acceptable range. However, with UCB HPCs some groups have reported controlled rate cooling to be superior with all other variables kept consistent [35]. There are actually advantages and disadvantages to both methods if utilized for UCB HPCs. Uncontrolled 'dump freezing' can be a low cost method, however it tends to yield variable results, and most methods do not provide recorded thermal profiles. Additionally, if back-up power generating capacity must be installed the cost-savings can be diminished. A common form of 'dump freezing' relies on placing the samples into an expanded-polystyrene box prior to placing into a $-85^{\circ} \mathrm{C}$ freezer. This method is relatively unrepeatable because the boxes used are not standardized. Controlled rate freezers overcome these limitations, but do so at the price of complexity which may increase the probability of failure due to component malfunction during the freeze cycle.

Most controlled rate freezers utilize mechanical valves, and the solenoids that drive them are exposed to very extreme conditions every time a sample is frozen. When the valve opens, it is often initially very near room temperature and is very rapidly cooled to the temperature of the nitrogen flowing through the valve, $-196{ }^{\circ} \mathrm{C}$. This introduces high thermal strains inside the component as it cools down. This repeated application of stress and strain result in fatigue cracks forming in the valves, eventually causing the valves or solenoids to fail. If failure occurs while a live sample is being frozen, a person must be on hand to place the sample in a different freezer or some other backup cooling system to save the sample. New controlled rate freezers are being developed and have been used in the reproductive cryopreservation setting which eliminate the need for solenoid valves altogether. One such device utilizes a Stirling engine to cool samples, so no liquid nitrogen is required at all [43]. While this device is efficient for smaller samples and is ideal in situations where risk of contamination
Fig. 1. Device for optimized 'dump' freezing of UCB samples. The device is constructed from 14 gauge aluminum plate surrounding characterized polyethylene foam determined to yield $1{ }^{\circ} \mathrm{C} /$ min cooling rates from room temperature to $-80^{\circ} \mathrm{C}$

when placed into a $-85^{\circ} \mathrm{C}$ mechanical freezer. An integrated thermocouple system mounted in the chamber is used with a 'dummy' bag in a canister for recording cooling rate profiles. This system has been shown to provide statistically comparable CFU outcomes from peripheral blood HPC as compared to standard controlled rate freezing methods.

is an issue (e.g. GMP settings), they are yet to be optimized for use with larger volumes such as blood bags.

In environments where the same controlled rate freezer is used to freeze many different samples with different cooling rates, controlled rate freezers are very appropriate due to their flexibility. In clinical laboratory environments, however, there is often a single cooling rate desired as the laboratory only handles one specific type of cell. In these cases it is not necessary to have a selectable cooling rate and a simpler system will suffice. Recently, such a system was developed at the University of Washington (fig. 1) [44]. This system was built from 14 gauge aluminum plate surrounding characterized polyethylene foam $\left(2.2 \mathrm{lb}\right.$ foam with $35.2 \mathrm{~kg} / \mathrm{m}^{3}$ density and $0.072 \mathrm{~W} / \mathrm{mK}$ conductivity) determined to yield $1{ }^{\circ} \mathrm{C} / \mathrm{min}$ cooling rates from room temperature to $-80{ }^{\circ} \mathrm{C}$ when placed into a $-85{ }^{\circ} \mathrm{C}$ mechanical freezer. An integrated thermocouple system was mounted in the chamber to be used with a 'dummy' bag in a canister for recording cooling rate profiles utilizing an FDA 21 CFR Part 11-compliant recording system. This system has been shown to provide statistically comparable CFU outcomes from peripheral blood HPCs as compared to standard controlled rate freezing methods [44]. Overall, this system allows traceability and reproducibility with a simple, convenient method and eliminates the need for control systems, liquid nitrogen consumption and failure prone components of the controlled rate freezer.

\section{Preparing Cells for Use}

In general, there is uniform agreement in the literature that rapidly thawing frozen UCB HPCs at rates of approximately $100{ }^{\circ} \mathrm{C} /$ min utilizing a $37^{\circ} \mathrm{C}$ water bath results in the best postthaw recovery and viability of cells [20, 29, 34]. These fast warming rates relative to the slow cooling rates likely reduce the chance of any small, innocuous intracellular ice nuclei that might have formed during freezing from recrystallizing and forming large, damaging intracellular ice [40]. Many centers 
in the USA also utilize the DMSO removal methods developed by Rubenstein et al. [19] prior to transplanting the cells. It is important to note here that the osmotic consequences of DMSO removal are potentially more damaging than the addition. The exact nature of osmotic injury remains largely unknown though several mechanisms have been proposed. The plasma membrane may rupture in hyposmotic conditions as a result of excessive cell expansion. Meryman [45] proposed that cell shrinkage in hypertonic conditions is resisted at high osmolalities and that further shrinkage damages the plasma membrane. Steponkus et al. [46] showed that loss of membrane lipids during cell shrinkage reduces the expansion potential of the cell and limits the subsequent increase in volume tolerated by the cell during rehydration. During subsequent thawing and return to isotonic medium, cells may swell beyond their normal isotonic volume and tend to lyse. Mazur [40] proposed that this may be due to the high salt concentrations that occur during freezing, which may increase the permeability of the plasma membrane and result in a net influx of solute. Studies of numerous cell types, including human granulocytes, platelets and spermatozoa, have shown that the range of solution osmolalities tolerated by cells may vary with the cell type, the temperature of the anisosmotic exposure, and the assay used to measure survival. Our group previously characterized the osmotic parameters of UCB-derived CD34+ cells, and similar work was independently performed by Hunt et al. $[28,33]$. The data from both laboratories were in very close agreement and indicated that multi-step removal of DMSO is ideal. It is important to remember that if the DMSO is not carefully removed prior to transplant, it is in effect removed in one step in vivo post-transplant, when DMSOloaded cells are introduced into the patient's body.

Recently, a method for infinite stepwise removal of DMSO from cell products through dialysis was proposed and characterized through mathematical modeling procedures [47]. Based on this work, a novel cell type-specific, closed system diffusion-washing device was developed (without the need for centrifugation) for use in removal of DMSO from HPC grafts, to prevent cell clumping, cell loss, and osmotic injury. This method and design is similar in concept to a hemodialyzer, but is much smaller in size and is specifically designed to remove DMSO from cryopreserved HPCs. Briefly, the cryopreserved cell suspension (UCB units) containing DMSO is run through hollow, porous membrane fibers inside the cylindrical jacket of a dialysis cartridge. The dialysis cartridge contains 500 cellulose-triacetate membrane fibers, with an internal diameter of $100 \mu \mathrm{m}$, a $15 \mu \mathrm{m}$ membrane thickness, and a porosity of $70 \%$. Isotonic perfusion medium (dialysate) is then pumped into the dialyzer and flows in the opposite direction in the interstices among the hollow fibers. Using this counter-flow dialysis approach, DMSO diffuses from cell suspension into the perfusion medium across the fiber membranes. The washed cell suspension continues to be re-circulated by automated pumps through the dialyzer continuously in this closed system until the DMSO is removed from the cell suspension. As systems such as this become more available, alternatives to the 'Rubenstein wash' method may become more widespread.

\section{An Optimized Procedure?}

Obviously, some discrepancies remain in the various studies set out to ultimately optimize UCB cryopreservation processing. Taken together, the closest consensus seems to be the use of $5-10 \%$ DMSO, added quickly, and then cooling at $1-2.5^{\circ} \mathrm{C} / \mathrm{min}$, followed by rapid thawing. Our group recently investigated application of our theoretically optimized protocol that yielded superior post-thaw engraftment for isolated CD34+ cells into NOD/SCID mice from UCB with whole MNCs prepared as for clinical use. In this experiment, UCB MNCs processed by hetastarch $\left(\right.$ Hespan $^{\circledR}$; B. Braun Medical Inc., Bethlehem, PA, USA) red blood cell depletion and plasma expression were cryopreserved using 5 or $10 \%$ DMSO prepared in autologous plasma at 1 or $4{ }^{\circ} \mathrm{C} / \mathrm{min}$. Results (HPC viability) were initially determined post freeze/thaw/ DMSO removal via culture in a semi-solid complete methylcellulose medium (Stem Cell Technologies, Vancouver, Canada) described previously [29]. Cultures were established in triplicate plates and scored with an inverted microscope at 14 days for presence of CFU-E, BFU-E, CFU-GM, and CFUGEMM. Further evaluations were conducted by using a human long-term culture-initiating cell (LTC-IC) assay as previously described [48]. The AFT024 stromal line was used in these assays, and (briefly) these cells were grown to confluence in 96-well plates and irradiated (2 Gy) [49]. Cryopreserved UCB samples were incubated (22 replicates per concentration: 3,11, 33, 100, 300, 900, and 2,700 cells/well) in LTC-IC medium (Iscove's modified Dulbecco's medium with $12.5 \%$ fetal calf serum, $12.5 \%$ horse serum, $2 \mathrm{mmol} / \mathrm{l}$ L-glutamine, $1 \mathrm{mmol} / \mathrm{l}$ hydrocortisone, $100 \mathrm{U} / \mathrm{ml}$ penicillin, and $100 \mu \mathrm{g} / \mathrm{ml}$ streptomycin). Over a period of 5 weeks, half of the medium was changed weekly. After 5 weeks, most of the medium was removed and each well overlayed with complete methylcellulose medium. The plates were finally scored for the number of positive wells and the frequency of LTC-IC determined.

The results of the initial experiments utilizing colony formation assays were surprising. Normalized as a percent of control cultures in which cells were manipulated but not exposed to DMSO or frozen, UCB MNCs cryopreserved using 5\% DMSO at $4{ }^{\circ} \mathrm{C} / \mathrm{min}$, the best protocol for isolated CD34+ cells, gave the worst results at $60.3 \pm 9.4 \%$ (mean percent of control \pm SEM). Using $10 \%$ DMSO at $4{ }^{\circ} \mathrm{C} / \mathrm{min}$ was slightly better, with $74.0 \pm 7.0 \%$. The best results seemed to be from $5 \%$ DMSO cooled at $1{ }^{\circ} \mathrm{C} / \mathrm{min}$, with $91.6 \pm 19.8 \%$, while $10 \%$ DMSO cooled at $1{ }^{\circ} \mathrm{C} / \mathrm{min}$ provided $89.7 \pm 2.8 \%$. There was no significant difference in concentrations within cooling rates but the cooling rates themselves were significantly different $(\mathrm{p}<0.05)$. 


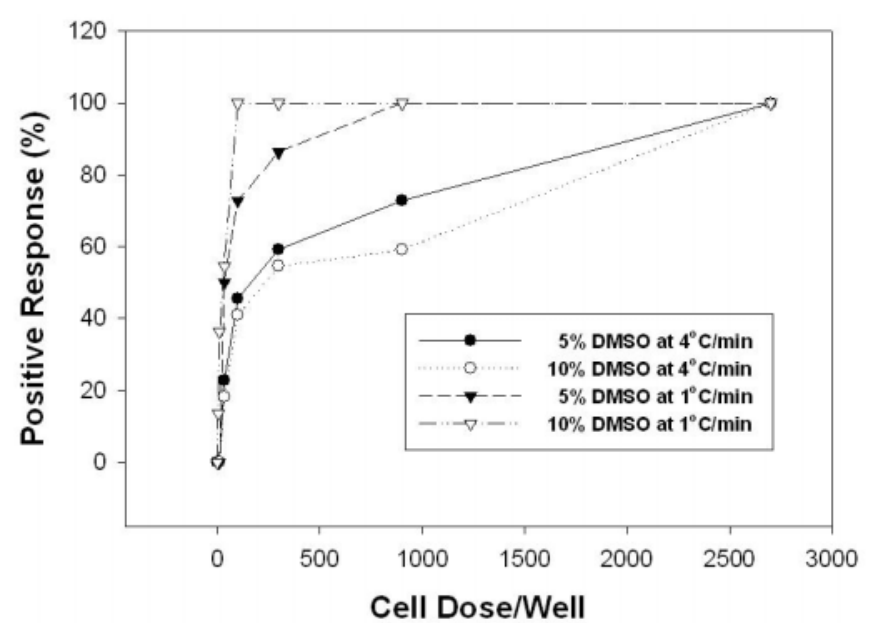

Fig. 2. LTC-IC results from UCB mononuclear cell preparations frozen using 5 or $10 \%$ DMSO at rates of 1 or $4{ }^{\circ} \mathrm{C} / \mathrm{min}$ (the method found optimal for isolated CD34+ cells). While no significant difference was observed for different concentrations of DMSO within each cooling rate, cooling rates were found to be significantly different $(\mathrm{p}<0.05)$.

The results of the LTC-IC assay indicated slightly better results using $10 \% \mathrm{DMSO}$ at $1{ }^{\circ} \mathrm{C} / \mathrm{min}$, but these were not significantly different from results achieved using 5\% DMSO (fig. 2). Again, cooling at $4{ }^{\circ} \mathrm{C} / \mathrm{min}$ using either DMSO concentration yielded worse outcomes.

These results give further support that $5 \%$ DMSO may be sufficient at cooling rates of $1{ }^{\circ} \mathrm{C} / \mathrm{min}$. The reason for the difference in results with MNC preparations as compared to isolated CD34+ cells is likely related to the presence of the various other cells in the MNC preparation. A percentage of the cells in the MNC component are granulocytes, which can express damaging chemicals into the intracellular environment upon lysis. Yang et al. [50] previously showed that MNC preparations frozen using a similar slow cooling protocol resulted in $99.5 \%$ recovery of CD34+ cells with only a $46 \%$ recovery of granulocytes.

Finally, while not in agreement with our previous results for isolated CD34+ cells, these recent results are in agreement with other recent studies investigating peripheral blood-derived HPCs cryopreserved and assayed using the LTC-IC method. In the recent study by Abrahamsen et al. [51] 12 of 15 samples showed higher numbers of LTC-colony forming cells after cryopreservation with $5 \%$ DMSO as opposed to $10 \%$ DMSO.

\section{Discussion}

UCB offers numerous clinical benefits, including its high concentration of HPCs and ability to be cryopreserved and stored in cord blood banks (CBB) for extended periods of time, available for use immediately. UCB transplantation is associ- ated with a low incidence of acute GVHD, along with more flexible donor and recipient HLA matching (tolerance of 1-2 antigen HLA mismatches) [52]. However, there have been limitations encountered with the use of UCB for HPC transplant. First, the number of progenitor cells in the HPC graft is vital for good engraftment and survival of the patient. The cell dose of a single UCB unit is fixed, leaving many adults that could benefit from an HPC transplant relying on a bone marrow donor. Second, collection of UCB from an individual is a one-time event, leaving physicians and researchers without the ability to collect more HPCs in case of disease relapse or poor engraftment. Third, there is less experience and expertise with the use of UCB for HPC transplant than for more traditional sources such as bone marrow. Finally, pre-transplantation manipulation and preservation of UCB cells is relatively new and yet to be optimized.

Despite the fact that UCB transplant is still a relatively new field, it has nevertheless proven successful in the treatment of thousands of children with malignant and nonmalignant disorders. UCB is well established in the pediatric transplant setting, and it is considered a safe and often preferred alternative to bone marrow or peripheral blood. This is due most notably to the high likelihood of finding a suitable HLA-matched UCB unit and the lower rate of acute GVHD. However, in adults the use of UCB for HPC transplant is much less routine than in children, due to low HPC doses in UCB that prevents adults and larger adolescents from undergoing UCB transplant. In 2004-2005, approximately $25 \%$ of adults in need of a transplant were able to find UCB samples with the required cell dose of $2.5 \times 10^{7}$ nucleated cells $/ \mathrm{kg}$, although close to 200,000 UCB units were listed in storage in the world's CBBs at the time [53].

Despite this obstacle, Laughlin et al. [54] recently reported the successful transplant of a large series of adults with UCB grafts from unrelated donors. Through the use of two unrelated, partially matched UCB units, it is possible to achieve a sufficient number of HPCs to engraft into adult patients [55]. By using two UCB units that share 4 of 6 HLA-A, HLA-B, and DRB1 antigens with the recipient and each other, Kai et al. [56] and Barker et al. [57] in independent studies reported successful, improved engraftment. Treatment-related mortality and survival appear to be superior in adults that underwent double UCB transplant as compared to other studies not using this technique, such as Rocha et al. [58]. It is reasonable to conclude that the use of two UCB units might be enough to overcome the cell dose limitations of UCB for HPC transplant in adults.

Additionally, more studies must be conducted and larger numbers of patients need to be treated before we have a firm grasp on the specific types of diseases and patients that can benefit specifically from UCB HPC transplant. The use of double UCB grafts needs further investigation along with other promising UCB approaches. As we gain more experience in the use of UCB for HPC transplant, it will become clearer 


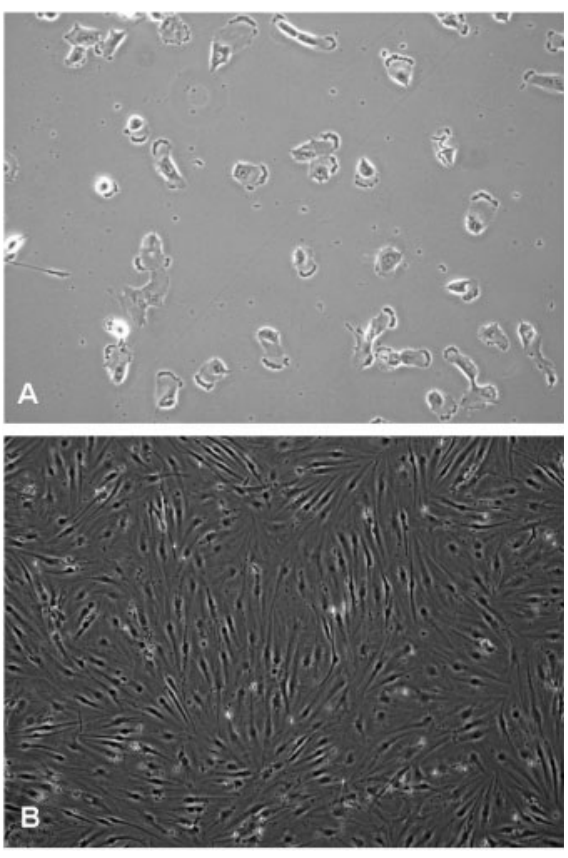

Fig. 3. Photomicrographs of MPCs grown from $\mathrm{UCB}$ $\mathrm{MNC}$ preparations frozen using the protocol optimized for HPC cryopreservation. A Thawed and washed cells after 6 days of culture on tissue culture treated flasks; B thawed and washed cells after 20 total days of culture, approaching confluence. optimized for HPC preservation. Though not quantified, each of 5 units cultured yielded MPCs, which exhibited CFU-F morphology under appropriate culture conditions (fig. 3). These results indicate that cryopreserved UCB units may be useful as an alternative source of these cells for both experimental and therapeutic applications.

Recent reports have shown that extrinsic signals, such as soluble factors and adhesion/matrix proteins provided by the stem cell microenvironment or stem cell 'niche', play a crucial role in the asymmetric division of stem cells and maintenance of the stem cell pool $[64,65]$. Accordingly, several groups have reported expansion of hematopoietic progenitors in the presence of stromal elements and other types of feeder layers, with varying outcomes [66-68]. Human MPCs not only provide a rich environment of cytokines, extracellular matrix proteins and adhesion molecules, but also, unlike stromal cells, produce leukemia inhibitory factor (LIF), a cytokine that has been shown to maintain embryonic stem cells in a self-replicative state $[69,70]$. Moreover, it has been shown that hematopoietic progenitor cells cultured on MPCs form cobblestone areas reaching deep into the MPC layer, suggestive of establishment of close contact and a 'niche'-like environment [71].

Studies have shown that MPCs secrete, at baseline, IL-6, IL-7, IL-8, IL-11, IL-12, IL-14, and IL-15, macrophage-colony-stimulating factor (MCSF), flt-3 ligand (FL), and stem cell factor (SCF), similar to the cytokines and growth factors expressed by marrow-derived stromal cells [71]. Accordingly, MPCs have been shown, similar to Dexter-type stromal cells, to support LTC-IC colonies during prolonged in vitro bone marrow culture [72]. Importantly, however, IL-1 $\alpha$-stimulated MPCs, but not bone marrow-derived stromal cells, secrete LIF, which has been shown to inhibit embryonic stem cell differentiation [69-71].

Studies designed to compare in vitro readouts of UCB cultured days in the presence of cytokines with or without MPCs as a feeder layer support the hypothesis that MPCs may preserve early CD34+ progenitor potential by reducing differentiation-induced cell cycle progress and apoptosis, and may thus contribute to the preservation/expansion of this early progenitor cell pool.

MPCs express HLA class I antigens and do not express HLA class II nor a full complement of costimulatory adhesion molecules under normal conditions [64]. MPCs could, thus, exert a tolerizing effect on UCB graft lymphocytes during expansion, possibly resulting in MPC antigen-specific tolerance. This could allow expansion of UCB on MPCs derived from the prospective recipient and, thus, to tolerize the graft to its recipient, potentially reducing GVHD after transplantation. Conversely, the presence of cytokines, such as FL, IL-3, and IL-6, could result in highly activated UCB graft lymphocytes, potentially resulting in severe graft-versus-host reactions after infusion of the expanded cells [73].

The presence of MPCs during expansion with cytokines, including FL, IL-3, and IL-6, did not result in the activation of 
UCB lymphocytes nor the acquisition of memory against MSC donor-specific antigens [73]. Kadereit et al. [73] also found that it did not result, either, in the acquisition of MSC donor antigen-specific tolerance. The latter would potentially allow specific tolerization of the graft to the prospective recipient by deriving MPCs from the recipient prior to transplantation, thereby potentially reducing graft lymphocyte reactivity to the patient. The UCB stem cell product after expansion in the presence of MPCs would, therefore, not be expected to generate a strong graft-versus host reaction in vivo and may, therefore, be suitable for clinical application.

There are some in vivo animal data supporting the use of MPCs to enhance UCB engraftment. In the context of utilizing two UCB units from different donors as a strategy for use of UCB in larger patients, clinical trials have revealed that cells from one donor UCB unit usually dominate engraftment. To explore this phenomenon further, Kim et al. [74] performed mixed transplantation of two UCB units with varying degrees of HLA disparities into NOD/SCID mice and determined donor origins by polymerase chain reaction techniques. With the double transplant technique, cells from one donor predominated in a ratio of $81: 19$, despite comparable overall engraftment when units were infused alone. However, cotransplantation of MPCs expanded from bone marrow resulted in more balanced co-engraftment. A direct comparison of double UCB transplant in the presence or absence of MPCs showed that the reduced deviation in donor ratio (1.8:1 versus 2.8:1) correlated with a higher level of engraftment in cotransplantation of MPCs. The results of Kim et al. [74] suggest that co-transplantation of MPCs in UCB transplant aid in alle- viating donor deviation and facilitate engraftment of multidonor UCB units. Other reports also suggest that MPCs may be a useful tool to enhance engraftment and to prevent and treat GVHD [15, 76].

The ultimate impact of UCB may be far more significant than now considered, meaning that research in this area should continue to grow. Overall, clinical data justifies further development of CBBs worldwide. Cryopreservation processing that yields consistent high recovery of functionally viable cells is crucial for the further successful use of this important cell resource. Due to advances in transplantation, increased experience, and ongoing clinical trials, patient eligibility for transplant continues to expand, and the list of indications for which UCB transplant may be a standard treatment option continues to develop. Public CBBs must focus on processing and cryopreservation of UCB units with large numbers of total nucleated cells and CD34+ cells. Also, CBBs must continue to make an effort to bank cells from ethnic and racial minorities. If CBBs preserve UCB units with large numbers of cells from diverse backgrounds, UCB will quickly become the preferred source of HPCs for transplant. Multiple research paths are being explored and continue to emerge, strengthening UCB transplant outcomes and representing significant advances in the field.

\section{Acknowledgements}

This work was funded by grants from the NIH-NHLBI (R43 HL65864A to EJW) and by General BioTechnology, LLC.

\section{References}

1 Hall PA, Watt FM: Stem cells: the generation and maintenance of cellular diversity. Development 1989;106:619-633.

2 Bruder SP, Jaiswal N, Haynesworth SE: Growth kinetics, self-renewal, and the osteogenic potential of purified human mesenchymal stem cells during extensive subcultivation and following cryopreservation. J Cell Biochem 1997;64:278-294.

>3 Korbling M, Estrov Z: Adult stem cells for tissue repair - a new therapeutic concept? N Engl J Med 2003;349:570-582.

4 Horowitz MM: Uses and growth of hematopoietic cell transplantation; in Blume KG, Forman SJ, Appelbaum FR (eds): Thomas' Hematopoietic Cell Transplantation, 3rd ed. Malden, Blackwell, 2004, pp 9-15.

$\checkmark 5$ Kernan NA, Bartsch G, Ash RC, Beatty PG, Champlin R, Filipovich A, Gajewski J, Hansen JA, Henslee-Downey J, McCullough J, et al: Analysis of 462 transplantations from unrelated donors facilitated by the National Marrow Donor Program. N Engl J Med 1993;328:593-602.

6 Adamson JW: Cord blood stem cell banking and transplantation. Stem Cells 1997;15(suppl 1):57-61.

7 Gluckman, E: The therapeutic potential of feta and neonatal hematopoietic stem cells. N Engl J Med 1996;335:1839-1840.
8 Kurtzberg J, Laughlin M, Graham ML, Smith C, Olson JF, Halperin EC, Ciocci G, Carrier C, Stevens CE, Rubinstein P: Placental blood as a source of hematopoietic stem cells for transplantation into unrelated recipients. N Engl J Med 1996; 355:157-166.

9 Wagner JE, Rosenthal J, Sweetman R, Shu XO, Davies SM, Ramsay NK, McGlave PB, Sender L, Cairo MS: Successful transplantation of HLA matched and HLA mismatched umbilical cord blood from unrelated donors: analysis of engraftment and acute graft vs. host disease. Blood 1996; 88:795-802.

10 Rubinstein P, Carrier C, Scaradavou A, Kurtzberg J, Adamson J, Migliaccio AR, Berkowitz RL, Cabbad M, Dobrila NL, Taylor PE, Rosenfield RE, Stevens CE: outcomes among 562 recipients of placental-blood transplants from unrelated donors. N Engl J Med 1998;339:1565-1577.

11 Sousa T, de Sousa ME, Godinho MI Mendes C, Carvalhais A, Barbosa IL: Umbilical cord blood processing: volume reduction and recovery of CD34+ cells. Bone Marrow Transplant 1997;19: 311-313.
12 Gluckman E, Broxmeyer HA, Auerbach AD, Friedman HS, Douglas GW, Devergie A, Esperou H, Thierry D, Socie G, Lehn P, et al: Hematopoietic reconstitution in a patient with Fanconi's anemia by means of umbilical-cord blood from an HLA-identical sibling. N Engl J Med 1989;321:1174-1178.

13 Lee MW, Choi J, Yang MS, Moon YJ, Park JS, Kim HC, Kim YJ: Mesenchymal stem cells from cryopreserved human umbilical cord blood. Biochem Biophys Res Commun 2004;320:273-278.

14 Lazarus HM, Koc ON, Devine SM, Curtin P, Maziarz RT, Holland HK, Shpall EJ, McCarthy P, Atkinson K, Cooper BW, Gerson SL, Laughlin MJ, Loberiza FR Jr, Moseley AB, Bacigalupo A: Cotransplantation of HLA-identical sibling cultureexpanded mesenchymal stem cells and hematopoietic stem cells in hematologic malignancy patients. Biol Blood Marrow Transplant 2005;11:389-398.

15 Le Blanc K, Rasmusson I, Sundberg B, Gotherstrom C, Hassan M, Uzunel M, Ringden O: Treatment of severe acute graft-versus-host disease with third party haploidentical mesenchymal stem cells. Lancet 2004:363:1439-1441.

16 Horwitz EM, Prockop DJ, Gordon PL, Koo WW, Fitzpatrick LA, Neel MD, McCarville ME, Orchard PJ, Pyeritz RE, Brenner MK: Clinical responses to bone marrow transplantation in children with severe osteogenesis imperfecta. Blood 2001;97: 1227-1231 
17 Koc ON, Day J, Nieder M, Gerson SL, Lazarus HM, Krivit W: Allogeneic mesenchymal stem cell infusion for treatment of metachromatic leukodystrophy and Hurler syndrome. Bone Marrow Transplant 2002;30:215-222.

18 Chang YJ, Tseng CP, Hsu LF, Hsieh TB, Hwang SM: Characterization of two populations of mesenchymal progenitor cells in umbilical cord blood. Cell Biol Int. 2006;30:495-499.

19 Rubinstein P, Dobrila L, Rosenfeld RE: Processing and cryopreservation of placental/umbilical cord blood for unrelated bone marrow reconstitution. Proc Natl Acad Sci U S A 1995;92:10119-10122.

20 Skoric D, Balint B, Petakov M, Sindjic M, Rodic P: Collection strategies and cryopreservation of umbilical cord blood. Transfus Med 2007;17:107-113.

21 Sputtek A: Kryokonservierung von Blutzellen und hämatopoetischen Stammzellen; in Müller-Eckhardt C, Kiefel V (Hrsg): Transfusionsmedizin. Berlin, Springer, 2004, pp 133-144.

-22 Sputtek A, Gutensohn K, Hummel K, Löliger C, Kühnl P: Zur Kryokonservierung von Blutstammzellen. J Lab Med 1996;20:70-77.

23 Körber C, Scheiwe MW, Boutron P, Rau G: The influence of hydroxyethyl starch on ice formation in aqueous solutions. Cryobiology 1982;19:478-492.

24 Sputtek A, Sputtek R: Cryopreservation in transfusion medicine and hematology; in Fuller BJ, Lane N, Benson EE (eds): Life in the Frozen State. Boca Raton, CRC Press, 2004, pp 483-502.

25 Mazur P: Freezing of living cells: mechanisms and implications. Am J Physiol 1984;247:C125-C142.

26 Gao DY, Liu J, Liu C, McGann LE, Watson PF, Kleinhans FW, Mazur P, Critser ES, Critser JK: Prevention of osmotic injury to human spermatozoa during the addition and removal of glycerol. Hum Reprod 1995;10:1109-1122.

27 Mazur P, Leibo SP, Chu EHY: A two-factor hypothesis of freezing injury. Exp Cell Res 1972;71: 345-355.

28 Woods EJ, Liu J, Derrow CW, Smith FO, Williams DA, Critser JK: Osmometric and permeability characteristics of human placental/umbilical cord blood CD34+ cells and their application to cryopreservation. J Hematother Stem Cell Res 2003;9: 161-173.

29 Woods EJ, Liu J, Pollok K, Hartwell J, Smith FO, Williams DA, Yoder MC, Critser JK: A theoretically optimized method for cord blood stem cell cryopreservation. J Hematother Stem Cell Res 2003; 12:341-350.

-30 de Vries EGE, Vellenga E, Kluin-Nelemans JC, Mulder NH: The happy destiny of frozen haematopoietic stem cells: from immature stem cells to mature applications. Eur J Cancer 2004;40: 1987-1992.

31 Sputtek A, Jetter S, Hummel K, Kühnl P: Cryopreservation of peripheral blood progenitor cells: characteristics of suitable techniques; in Sibrowski W, Stangel W, Blauhut B (Hrsg): Transfusionmedizin 1995/96. Beitr Infusionsther Transfusionsmed. Basel, Karger, 1997, vol 34, pp 79-83.

32 Donaldson C, Armitage WJ, Denning-Kendall PA, Nicol AJ, Bradley BA, Hows JM: Optimal cryopreservation of human umbilical cord blood. Bone Marrow Transplant 1996;18:725-731.

33 Hunt CJ, Armitage SE, Pegg DE: Cryopreservation of cord blood: 1 . Osmotically inactive volume, hydraulic conductivity and permeability of CD34+ cells to dimethyl sulphoxide. Cryobiology 2003;46: $61-75$.
34 Hunt CJ, Armitage SE, Pegg DE: Cryopreservation of cord blood: 2. Tolerance of CD34+ cells to multimolar dimethyl sulphoxide and the effect of cooling rate on recovery after freezing and thawing. Cryobiology 2003;46:76-87.

35 Meyer TPH, Hofmann B, Zaisserer J, Jacobs VR, Fuchs B, Rapp S, Weinauer F, Burkhart J: Analysis and cryopreservation of hematopoietic stem and progenitor cells from umbilical cord blood. Cytotherapy 2006;8:265-276.

36 Douay L, Gorin NC, David R, Stachowiak J, Salmon C, Najman A, Duhamel G: Study of granulocyte-macrophage progenitor (CFUc) preservation after slow freezing of bone marrow in the gas phase of liquid nitrogen. Exp Hematol 1982;10: 360-366.

37 Rowley SD, Anderson GL: Effects of DMSO exposure without cryopreservation of hematopoietic progenitor cells. Bone Marrow Transplant 1993;11: 389-393.

38 Branch DR, Calderwood S, Cecutti MA, Herst R, Solh H: Hematopoietic progenitor cells are resistant to dimethyl sulfoxide toxicity. Transfusion 1994;34:887-890.

39 Liu J, Zieger MAJ, Lakey JRT, Woods EJ, Critser JK: The determination of membrane permeability coefficients of canine pancreatic islet cells and their application to islet cryopreservation. Cryobiology 1997:35:1-13.

40 Mazur P: Equilibrium, quasi-equilibrium and nonequilibrium freezing of mammalian embryos. Cell Biophys 1990;17:53-92.

41 Choi CW, Kim BS, Seo JH, Shin SW, Kim YH, Kim JS: Long-term engraftment stability of peripheral blood stem cells cryopreserved using the dumpfreezing method in a $-80{ }^{\circ} \mathrm{C}$ mechanical freezer with $10 \%$ dimethyl sulfoxide. Int J Hematol 2001; 72:245-250.

42 Muramaki M, Hara I, Miyake H, Yamada Y, Okada H, Kamidono S: Long-term cryopreservation of peripheral blood stem cells in patients with advanced germ cell tumors using the dump-freezing method at $-80^{\circ} \mathrm{C}$. Oncol Rep 2003;10:1993-1998.

43 Morris GJ, Acton E, Faszer K, Franklin A, Yin H, Bodine R, Pareja J, Zaninovic N, Gosden R: Cryopreservation of murine embryos, human spermatozoa and embryonic stem cells using a liquid nitrogen-free, controlled rate freezer. Reprod Biomed Online 2006 13:421-426.

44 Purtteman J: Development of a controlled rate cooling instrument for cryopreservation of hematopoietic stem cells. Thesis, University of Washington, Department of Mechanical Engineering, 2006.

45 Meryman HT: Osmotic stress as a mechanism of freezing injury. Cryobiology 1971;8:489-500.

46 Steponkus PL, Wolfe J, Dowgert JF: Stresses induced by contraction and expansion during a freeze-thaw cycle: a membrane perspective; in Morris GJ, Clarke A (eds): Effects of Low Temperatures on Biological Membranes. New York, Academic Press, 1981, pp 307-322.

47 Ding W, Yu J, Woods E, Heimfeld S, Gao D: Simulation of removing permeable cryoprotective agents from cryopreserved blood with hollow fiber modules. J Membr Sci 2007;288:85-93.

48 Srour EF, Tong X, Sung KW, Plett PA, Rice S Daggy J, Yiannoutsos CT, Abonour R, Orschell $\mathrm{CM}$ : Modulation of in vitro proliferation kinetics and primitive hematopoietic potential of individual human CD34+CD38-/lo cells in G0. Blood 2005; 105:3109-116.
49 Theimann FT, Moore KA, Smogorzewska EM, Lemischka IR, Crooks GM: The murine stromal cell line AFT024 acts specifically on human CD34+CD38- progenitors to maintain primitive function and immunophenotype in vitro. Exp Hematol 1998;26:612-619.

50 Yang H, Acker JP, Hannon J, Miszta-Lane H, Akabutu JJ, McGann LE: Damage and protection of UC blood cells during cryopreservation. Cytotherapy 2001;3:377-386

51 Abrahamsen JF, Rusten L, Bakken AM, Bruserud O: Better preservation of early hematopoietic progenitor cells when human peripheral blood progenitor cells are cryopreserved with 5 percent dimethylsulfoxide instead of 10 percent dimethylsulfoxide. Transfusion 2004;44:785-789.

52 Rocha V,Wagner JE Jr, Sobocinski KA, Klein JP, Zhang MJ, Horowitz MM, Gluckman E: Graft-versus-host disease in children who have received a cord-blood or bone marrow transplant from an HLA-identical sibling. Eurocord and International Bone Marrow Transplant Registry Working Committee on Alternative Donor and Stem Cell Sources. N Eng. J Med 2000;342:1846-54.

53 Brunstein CG, Wagner JE: Cord blood transplantation for adults. Vox Sang 2006;91:195-205.

54 Laughlin MJ, Eapen M, Rubinstein P, Wagner JE, Zhang MJ, Champlin RE, Stevens C, Barker JN Gale RP, Lazarus HM, Marks DI, van Rood JJ, Scaradavou A, Horowitz MM: Outcomes after transplantation of cord blood or bone marrow from unrelated donors in adults with leukemia. N Engl J Med 2004;351:2265-2275.

55 Barker JN, Weisdorf DJ, Wagner JE: Creation of a double chimera after the transplantation of umbilical-cord blood from two partially matched unrelated donors. N Engl J Med 2001;344:1870-1871.

56 Kai S, Misawa M, Iseki T, et al: Double-unit cord blood transplantation in Japan. Blood 2004;104 5166a (abstract).

57 Barker JN, Weisdorf DJ, DeFor TE, Blazar BR, McGlave PB, Miller JS, Verfaillie CM, Wagner JE: Transplantation of 2 partially HLA-matched umbilical cord blood units to enhance engraftment in adults with hematologic malignancy. Blood 2005; 105:1343-1347.

58 Rocha V, Labopin M, Sanz G, Arcese W, Schwerdtfeger R, Bosi A, Jacobsen N, Ruutu T, de Lima M, Finke J, Frassoni F, Gluckman E: Transplants of umbilical-cord blood or bone marrow from unrelated donors in adults with acute leukemia. N Engl J Med 2004;351:2276-2285.

59 Orkin SH, Zon LI: Hematopoiesis and stem cells plasticity versus developmental heterogeneity. Nat Immunol 2002;3:323-328.

60 Goodwin HS, Bicknese AR, Chien SN, Bogucki BD, Quinn CO, Wall DA: Multilineage differentiation activity by cells isolated from umbilical cord blood: expression of bone, fat, and neural markers. Biol Blood Marrow Transplant 2001;7:581-588.

61 Deans RJ, Moseley AB: Mesenchymal stem cells: biology and potential clinical uses. Exp. Hematol 2000;28:875-884.

62 Jiang Y, Jahagirdar BN, Reinhardt RL, Schwartz RE, Keene CD, Ortiz-Gonzalez XR, Reyes M, Lenvik T, Lund T, Blackstad M, Du J, Aldrich S, Lisberg A, Low WC, Largaespada DA, Verfaillie CM: Pluripotency of mesenchymal stem cells derived from adult marrow. Nature 2002;418:41-49.

63 Romanov YA, Svintsitskaya VA, Smirnov VN: Searching for alternative sources of postnatal human mesenchymal stem cells: candidate MSClike cells from umbilical cord. Stem Cells 2003;21: 105-110. 
64 Verfaillie CM: Soluble factor(s) produced by human bone marrow stroma increase cytokine-induced proliferation and maturation of primitive hematopoietic progenitors while preventing their terminal differentiation. Blood 1993;82:2045-2053.

65 Clausen J, Stockschlader M, Fehse N, Hassan HT, Gabl C, Zander AR: Blood-derived macrophage layers in the presence of hydrocortisone support myeloid progenitors in long-term cultures of CD34+ cord blood and bone marrow cells. Ann Hematol 2000;79:59-65.

66 Verfaillie CM: Direct contact between human primitive hematopoietic progenitors and bone marrow stroma is not required for long-term in vitro hematopoiesis. Blood 1992;79:2821-2826.

67 Shimakura Y, Kawada H, Ando K, Sato T, Nakamura Y, Tsuji T, Kato S, Hotta T: Murine stromal cell line HESS-5 maintains reconstituting ability of ex vivo-generated hematopoietic stem cells from human bone marrow and cytokine-mobilized peripheral blood. Stem Cells 2000;18:183-189.

68 Kusadasi N, Koevoet JL, van Soest PL Ploemacher RE: Stromal support augments extended long-term ex vivo expansion of hemopoietic progenitor cells. Leukemia 2001;15:1347-1358

69 Gough NM, Williams RL, Hilton DJ, Pease S, Willson TA, Stahl J, Gearing DP, Nicola NA, Metcalf D: LIF: a molecule with divergent actions on myeloid leukaemic cells and embryonic stem cells. Reprod Fertil Dev 1989;1:281-288.

70 Murray P, Edgar D: The regulation of embryonic stem cell differentiation by leukaemia inhibitory factor (LIF). Differentiation 2001;86:227-234.

71 Majumdar MK, Thiede MA, Mosca JD, Moorman M, Gerson SL: Phenotypic and functional comparison of cultures of marrow-derived mesenchymal stem cells (MSCs) and stromal cells. J Cell Physiol 1998;176:57-66.

72 Majumdar MK, Thiede MA, Haynesworth SE, Bruder SP, Gerson SL: Human marrow-derived mesenchymal stem cells (MSCs) express hematopoietic cytokines and support long-term hematopoiesis when differentiated toward stromal and osteogenic lineages. J Hematother Stem Cell Res 2000;9:841-848

73 Kadereit S, Deeds LS, Haynesworth SE, Koc ON Kozik MM, Szekely E, Daum-Woods K, Goetchius GW, Fu P, Welniak LA, Murphy WJ, Laughlin MJ: Expansion of LTC-ICs and maintenance of p21 and BCL-2 Expression in cord blood CD34+/CD38early progenitors cultured over human MSCs as a feeder layer. Stem Cells 2002;20:573-582.

74 Kim DW, Chung YJ, Kim TG, Kim YL, Oh IH: Cotransplantation of third-party mesenchymal stromal cells can alleviate single-donor predominance and increase engraftment from double cord transplantation. Blood 2004;103:1941-1948.

76 Frassoni F, Labopin M, Bacigalupo A: Expanded mesenchymal stem cells, co-infused with HLAidentical hematopoietic stem cell transplant, reduce acute and chronic graft versus host disease: a matched-pair analysis. Bone Marrow Transplant 2002;29(suppl 2):75 